\title{
Memoria transitoria. El Centro Andaluz de Arte Contemporáneo cumple 25 años
}

\begin{abstract}
En marzo de 2015 se inauguraba la sesión expositiva 25 aniversario organizada por el Centro Andaluz de Arte Contemporáneo en conmemoración de la efémeride de su creación. El CAAC, cuya sede se encuentra en el Monasterio de la Cartuja de Sevilla, no sólo es el encargado de conservar y mantener este edificio, sino que también tutela la colección vinculada a su rica y variada historia. Es por esto que la programación conmemorativa de su 25 aniversario el Centro Andaluz de Arte Contemporánero combina los dos pilares de su actividad: el arte contemporáneo y el patrimonio histórico.
\end{abstract}

Juan Antonio Álvarez Reyes | director del Centro Andaluz de Arte Contemporáneo

URL de la contribución <www.iaph.es/revistaph/index.php/revistaph/article/view/3768>

Investigar y reflexionar sobre el pasado reciente es una tarea intrínseca para un museo de arte contemporáneo, a lo que debe sumar un análisis del presente y una prospección sobre el inmediato futuro. Estos tres tiempos deben acompasarse de una manera natural y decidida desde una perspectiva crítica. Más allá de las 200 exposiciones organizadas en estos años de andadura, de las 3.000 obras de arte que poco a poco se han ido reuniendo en su colección, del paulatino incremento del número de visitantes (un $68 \%$ más en los últimos cinco años), o de ser el único museo de gestión y titularidad totalmente autonómica en Andalucía, conviene señalar dos cuestiones de las que ha partido el equipo del CAAC para organizar su 25 aniversario: la memoria entendida de manera transitoria y el contexto espacial y temporal donde se ha desarrollado la actividad del centro.

El ciclo de 25 años de vida del CAAC se inició como se cierra ahora: en medio de una severa crisis económica. Si la de los años 90 se precipitó con la Primera Guerra del Golfo y el estallido de la burbuja inmobiliaria en Japón, la más reciente -aquella en la que aún estamos inmersos- tiene también una base financiera e inmobiliaria que ha provocado profundas desigualdades sociales que están en la base de posibles transformaciones. Es en esta situación y contexto en el que se ha pretendido analizar el arte que se ha ido produciendo de manera coetánea a los 25 años de vida del CAAC. Estudiando sucesivamente el rol del artista y cuestiones estéticas, culturales, sexuales, identitarias o sociales, se ha bus-

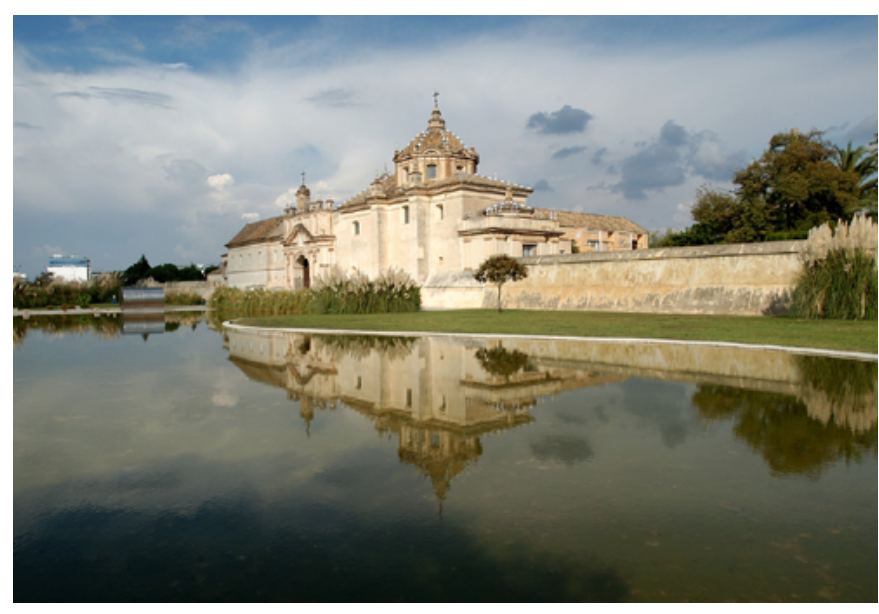

Panorámica de la entrada del CAAC | foto CAAC, titular de de todas las imágenes de la contribución

cado analizar el arte de las últimas décadas, partiendo del lugar donde nos encontramos.

El profesor norteamericano Andreas Huyssen ha señalado cómo en las últimas décadas se ha producido en Occidente un deslizamiento que privilegia la mirada hacia atrás frente a la que ponía el foco en las transformaciones que estarían a punto de llegar. Si la modernidad fue impulsada por lo que podría denominarse como "futuros presentes", la postmodernidad estaría caracterizada por los "pretéritos presentes".

Esta última noción aplicada a nuestro caso nace de una realidad que, lejos de ser una oposición, es un com- 
plemento a esta institución: el Centro Andaluz de Arte Contemporáneo tiene su sede en un complejo edificio que no sólo es un Bien de Interés Cultural, sino que forma parte de la Historia y está cargado de historias. El presente, el arte actual, producido en las últimas décadas, se muestra en un recinto del pasado que ha modificando sus funciones con los siglos. Ha sido ermita franciscana, monasterio cartujo desde 1399, cuartel militar durante la invasión napoleónica, fábrica de cerámica de 1841 a 1982, pabellón real durante la Exposición Universal de Sevilla de 1992, posteriormente conjunto monumental y, definitivamente, centro de arte contemporáneo desde 1997. Así, coincidiendo con su 25 aniversario, el CAAC organizó la primera retrospectiva del autor que recuperó la parte principal de su sede. José Ramón Sierra (Olivares, 1945) es decididamente un personaje singular que integra en su visión el trabajo en arquitectura junto al de artista visual, diseñador, profesor y escritor.

En el arte contemporáneo se han sucedido dos factores decisivos que fueron señalados en su momento por Susan Sontag y por Paul Virilio. Por un lado, como escribió la ensayista norteamericana en La estética del silencio, "los diversos públicos han experimentado la mayor parte del arte valioso de nuestro tiempo como un paso hacia el silencio (o hacia la ininteligibilidad, la invisibilidad o la inaudibilidad)". Por otro, el ensayista francés publicó en El procedimiento silencio que "Io audiovisual apunta a suprimir la integridad del silencio de la vista". Basándose en estos conceptos y a otros asociados a la vida cartuja, se puede comprobar cómo la soledad y el aislamiento, el silencio y la contemplación, pueden ser apreciados y sentidos en este lugar del mismo modo que son la base de algunos trabajos que durante nuestro 25 aniversario se han expuesto en nuestras salas.

Analizar el presente y otear el inmediato futuro son dos de los asuntos en los que se basa el proyecto que cerrará nuestro aniversario a finales de 2016. ¿Qué sienten, qué piensan, los artistas andaluces de ahora? parte del poema de Rafael Alberti Balada para los poetas andaluces de hoy, de 1953, que fue transformado en la canción Poetas andaluces de ahora por el grupo Aguaviva en el año 1969. El texto de Rafael Alberti fue una interpelación sobre el papel del arte y de los artistas ante una

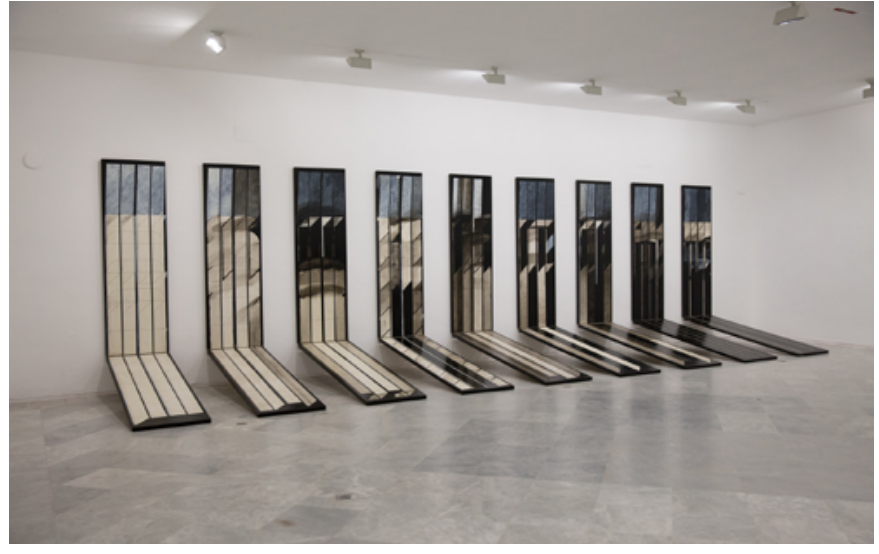

Exposición Zig-zag, José Ramón Sierra. Obra: Nueva paisajes de tormenta, 1983

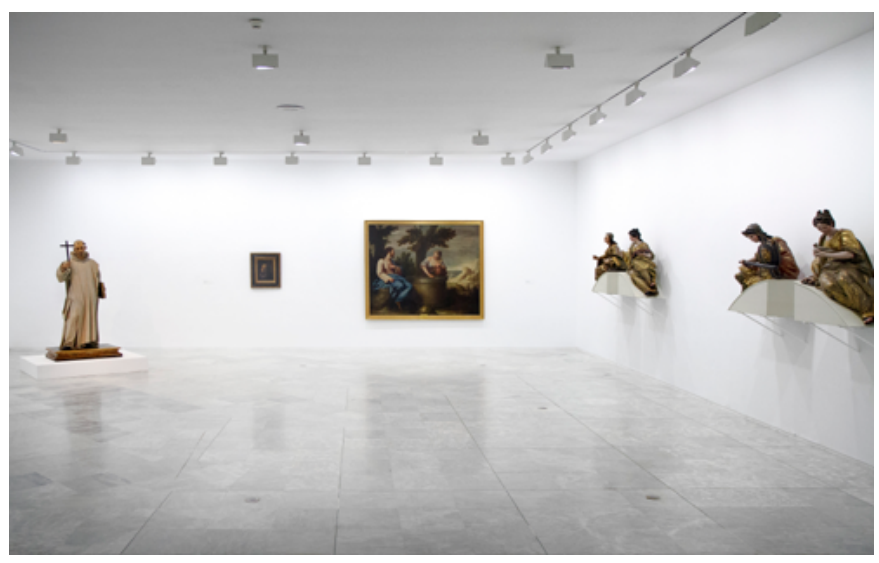

Sala de la exposición El Gran Silencio

determinada situación política y social. Así, también hoy la intención de este proyecto es trasladar este poema a la actualidad y al arte contemporáneo, de forma que los artistas de las últimas generaciones puedan mostrar lo que hacen y, por extensión, ofrecer al público determinadas visiones, algunas cercanas a lo que se ha denominado como "poesía de la conciencia".

La memoria, como señaló Huyssen, es siempre transitoria, y, en tanto que cuestión pública "está sometida al cambio político, generacional e individual". La memoria de estos 25 años del Centro Andaluz de Arte Contemporáneo, en tanto que se ha pretendido trabajar desde el pensamiento crítico, también está sometida al cambio desde una visión transformadora, pero ante todo, ha sido una labor colectiva. 